\title{
The Impact of Product Promotion and Innovation on Purchase Decisions at Prices as Intervening Variables
}

\author{
Joe Eklesia Apostolos Sujarwo ${ }^{*}$, Eko Suseno Hendro Riyadi Matruty ${ }^{2}$
}

1,2 The Faculty of Economics and Business, Satya Wacana Christian University, Salatiga, Indonesia

\section{ART ICLE IN F O}

Article history:

Received April 09, 2021

Revised April 10, 2021

Accepted May 02, 2021

Available online May 25, 2021

Keywords:

Promotion, Product Innovation

Price, Purchase Decision

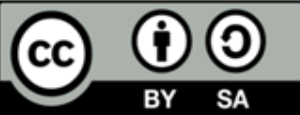

This is an open access article under the CC BY-SA license.

Copyright (@) 2021 by Author. Published by Universitas Pendidikan Ganesha.

\begin{abstract}
A B S T RA C T
Technological developments, especially in the field of digital marketing, in the new normal era this time had become a phenomenon that is no longer rare in society to carried out various activities, such as buying and selling online. The development of digital marketing in the new normal era is currently very fast. Several online shops that use digital marketing techniques such as Shopee and Tokopedia. This study aims to analyzed the effect of promotion and product innovation on purchasing decisions with price as an intervening variable. The research method used purposive sampling technique where the data is examined using measurements by considering individual choices. The sample collection used a questionnaire, and the number of samples used is 100 respondents. The analysis technique used multiple linear regression and multiple test. The results showed that the first hypothesis did not have a significant influence between the promotional variables on purchasing decisions. While the second hypothesis there is a significant influence between product innovation variables on purchasing decisions. Furthermore, the third and fourth hypothesis of the price variable mediate the relationship between promotion and product innovation on purchasing decisions.
\end{abstract}

\section{INTRODUCTION}

Technological developments, especially in the field of digital marketing, in the new normal era this time had become a phenomenon that is no longer rare in society to carried out various activities, such as buying and selling online (Hamdani et al., 2020; Handayani, 2018). As we knew, the internet is a promotional tool that has the aim of carried out various kinds of promotional activities and selling various kinds of products effectively and efficiently by using advertisements on the internet through social media which are currently growing very rapidly (Masda, 2019; Reza, 2017; Ainiyah, 2018). One of the online stores that are currently using digital marketing strategies is Tokopedia. William Tanuwijaya as CEO of Tokopedia revealed that millions of Indonesians have started individual businesses in the Tokopedia platform. In 2014, it can be seen from the number of visits by Tokopedia application users that it has reached 56 percent, but the transaction rate is around 29 percent. In 2016, it can be seen from the number of visits by Tokopedia application users of 79.55 percent, and the transaction rate has reached 73.58 percent. Furthermore, the online store that is well known among the public, both young people and the elderly, is Shopee. This online shop already provides a wide range of quality products, both National and International products where these products are marketed through the online market. Shopee entered the Indonesian market in May 2015, this online shop facilitates sellers to sell their products very easily and this online shop also facilitates buyers with a secure payment process (Margaretha, 2017 ; Japarianto, 2020).

Promotional variables had a significant effect on purchasing decisions. Because in making purchasing decisions, consumers are always focused on the promotions they get (Solihin, 2020). The promotion variable has an insignificant effect on purchasing decisions (Abdillah, 2017). This is important to research to see whether promotions had a positive or negative influence on the Tokopedia and Shopee platforms. So it is expected that the results of further research will provide new information about promotion as a variable that influences online purchasing decisions. Based on the resulted of the previous research where product innovation has a significant effect on purchasing decisions (Setiawan et al, 2018). Meanwhile, product innovation did not have a significant effect on purchasing decisions (Sekar, 2017). So that the two resulted above can be used as a research gap in research. Did product innovation had a 
positive or negative impact when it comes to purchasing decisions on the Tokopedia and Shopee platforms.

Based on previous research, the price used as an intervening variable had a positive and significant effect on online purchasing decisions (Dharma, 2017). So that when the price is increased or decreased it will affect the purchasing decisions. Price as an intervening variable did not have a positive effect on online purchasing decisions (Setyarko, 2016). Based on the resulted of calculations in the examiner's journal where the resulted of the regression analysis test showed a positive coefficient value of 0.088 . This can be concluded with a sig value $>0.05$, so that prices cannot mediate between promotions, product innovation and decisions. This research is important because it can apply that the price variable has the ability to determine the quality of promotion and the price of innovation which has an important role in influencing purchasing decisions. Based on the resulted of the research above, when there was a price changed, it will greatly affected purchasing decisions (Widyastuti, 2018). When a marketplace was promoting by attracting artists as brand ambassadors, it will affected the price of a product and purchase decision (Sriyanto, 2019). Likewise, if a product has continuous innovation every period, it will also affected the price (Akhiri, 2018). Therefore, the price chosen is the variable that intervenes which will be built by product innovation and promotion variables and influences consumers in deciding to buy through the Tokopedia and Shopee platforms.

By looking at this background, the goal of this research is to analyzed the effect of promotion to purchasing decisions, to analyze the effect of product innovation to purchasing decisions, to analyzed the effect of price as an intervening between promotions to purchasing decisions, to analyzed the effect of price as an intervening between product innovation to purchasing decisions. This research is expected to be useful for online shop companies Tokopedia and Shopee to choose products with prices, promotions and product innovation as references. In addition, this research is expected to provided information for companies in conducting company goods/services. The resulted of this research are expected to be used to deepen similar research for further research.

\section{METHODS}

This research was an explain research that proves the causal relationship between promotion factors and product innovation as independent variables and price as an intervening variable and purchasing decisions as the dependent variable (Kharis, 2017; Christian, 2013). The method used in this research was quantitative data. The data source used was primary data because the objects used are students who used shopee and tokopedia at Satya Wacana Christian University. In obtained primary data, the author used a questionnaire as a basis for obtaining answers from respondents. For every variable, the definition is taken from multiple sources written in Table 1.

Table 1. Operational Variable Definition

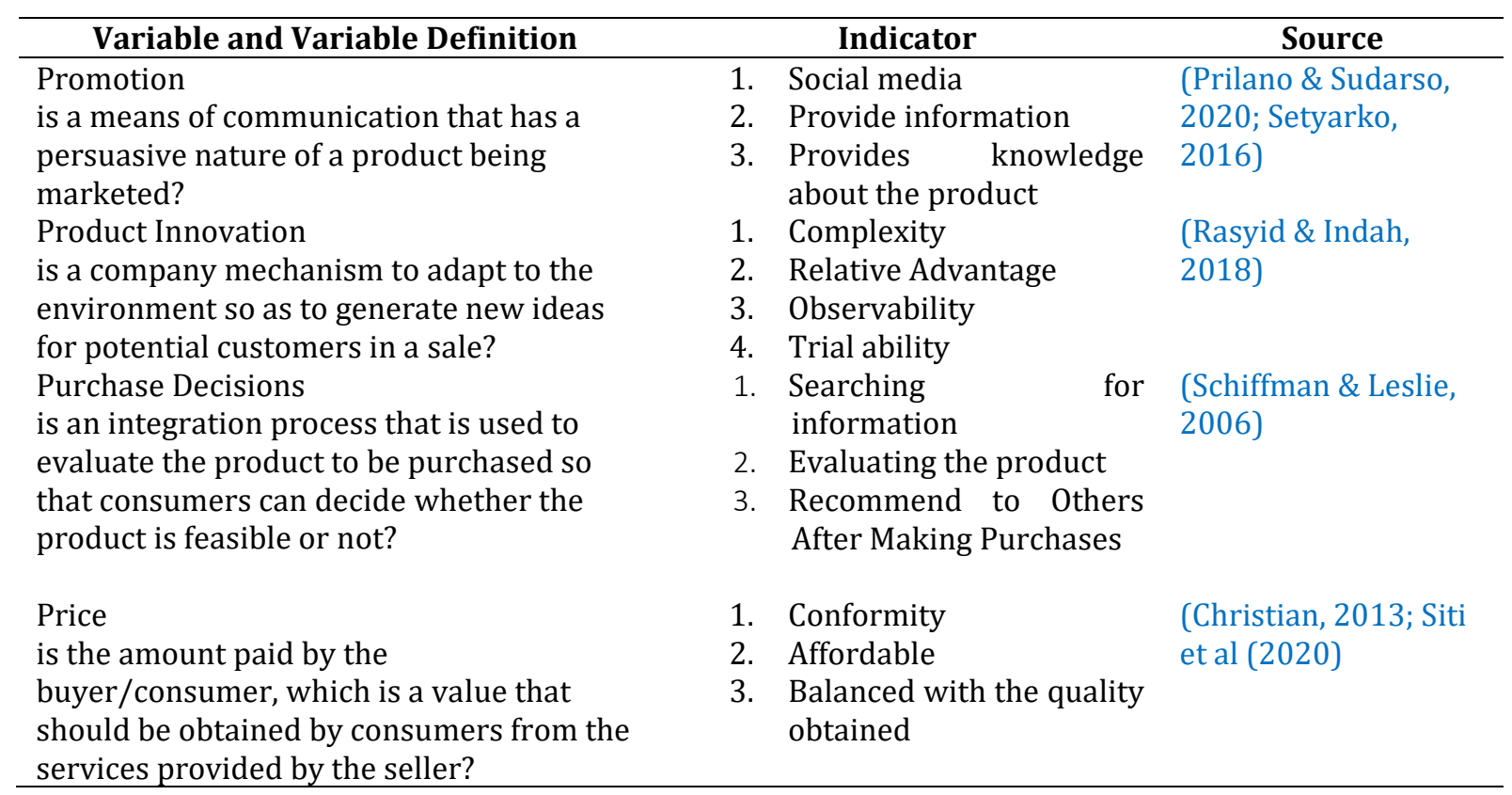


This research was using purposive sampling technique where the data is examined using measurements by considering individual choices by deliberately selecting respondents, where the population or respondents selected are respondents who did not believe and can provided the necessary information. In taking the sample the researcher chose the respondent with the criteria; Are active students of class 2017-2020 and class of 2016 who are still active as students of the faculty of economics and business with a target of 100 respondents. This research was conducted for students of the faculty of economics and business with the aim of providing information to the faculty regarding e-commerce usage data, so that it can be used as reference data for further research. The determination of the number of respondents in this study was determined based on the theory of previous experts, namely Roscoe (1975), where according to Roscoe a sample size of more than 30 and less than 500 is appropriate for most studies; Students who understand the ins and outs of the Tokopedia and Shopee platforms, understand all kinds of promotions and product innovations made by Tokopedia and Shopee; and students who used the Shopee and Tokopedia platforms who have made transactions at least 1 month prior to the research.

In this research, questionnaire was using as the data collecting method. The questionnaire was created using a Likert scale. The Likert scale was a scale that used several questions to measure a behavior and answered from respondents (Ghozali, 2012). On the Likert scale, the measurement used was five points of choice; (5) strongly agree, (4) agree, (3) neutral, (2) disagree, and (1) strongly disagree. To verified the proposed hypothesis, validity and reliability were tested to determine the accuracy of the questionnaire. Then the classical assumption test was carried out using SPSS 18. The classical assumption test includes the normality test, to measure the dependent variable and the independent variable on a data that is normally distributed or not. Furthermore, multi collinearity test to see no symptoms of multi collinearity symptoms. Then the heteroscedasticity test was to determine the variant discomfort in a regression. Furthermore, to carried out the influence of the mediating variables, an analysis was carried out first. Simple regression aims to prove research directly and indirectly. Then after that the determination coefficient test (R Square) was carried out which aims to test the Gooness-fit regression model, then $\mathrm{T}$ test to showed that the big influence from one variable to another. Furthermore, the Sobel test was carried out to test the effect of the intervening variable (Prayoga, 2020)

\section{RESULTS AND DISCUSSIONS}

Sources of research data used 100 respondents. From the data obtained, the largest number of respondents were women with a total of 78 respondents (78\%) and the remaining 22 male respondents $(22 \%)$. Furthermore, based on age, the largest number is 21 years with a total of 39 respondents (39\%). Second was the age of 20 with a total of 33 respondents (33\%). Meanwhile, based on the 2016-2020 class year, the most respondents were class 2018 with 44 respondents (44\%). The second is the 2017 class with 42 respondents (42\%). Respondent characteristics distribution is presented in Table 2.

Table 2. Respondent Characteristics Distribution

\begin{tabular}{cccc}
\hline Respondent Characteristic & & Frequency & Percentage \\
\hline Gender & Male & 22 & $22 \%$ \\
& Female & 78 & $78 \%$ \\
\hline \multirow{2}{*}{ Age } & TOTAL & $\mathbf{1 0 0}$ & $\mathbf{1 0 0 \%}$ \\
\cline { 2 - 4 } & $\leq 18$ & 3 & $3 \%$ \\
& 19 & 11 & $11 \%$ \\
& 20 & 33 & $33 \%$ \\
& 21 & 39 & $39 \%$ \\
& $\geq 22$ & 14 & $14 \%$ \\
\hline Class & TOTAL & $\mathbf{1 0 0} \%$ \\
& 2016 & 42 & $2 \%$ \\
& 2017 & 44 & $42 \%$ \\
& 2018 & 10 & $44 \%$ \\
& 2019 & 2 & $10 \%$ \\
\hline
\end{tabular}

\section{Hypothesis Test}

The result of regression test in this study is presented in Table 3. 
Table 3. Regression Test Result

\begin{tabular}{|c|c|c|c|c|c|}
\hline \multicolumn{6}{|c|}{ Coefficients } \\
\hline \multirow[t]{2}{*}{ Model } & \multicolumn{2}{|c|}{ Unstandardized Coefficients } & \multirow{2}{*}{$\frac{\text { Standardized Coefficients }}{\text { Beta }}$} & \multirow[t]{2}{*}{$\mathbf{t}$} & \multirow[t]{2}{*}{ Sig. } \\
\hline & B & Std. Error & & & \\
\hline 1 (Constant) & 11.294 & 1.673 & & 6.749 & 0.000 \\
\hline Promotion & -0.086 & 0.095 & -0.105 & -0.910 & 0.365 \\
\hline Innovation & 0.320 & 0.098 & 0.379 & 3.263 & 0.002 \\
\hline
\end{tabular}

Based on the simple linear regression equation, the regression coefficient value is 11.294 , which means if the promotion variable $\left(\mathrm{X}_{1}\right)$ and product innovation $\left(\mathrm{X}_{2}\right)$ are 0 , then the purchased decision variable (Y) will still be 11.294 and each additional unit in the promotional variable will reduced the purchase decision by -0.086 units; in the product innovation variable will increased the purchased decision as much as 0.320 units. Furthermore, the result of coefficient of determination in this study is presented in Table 4.

Table 4. Model Summary

\begin{tabular}{ccccc}
\hline Model & $\mathbf{R}$ & R Square & Adjusted R Square & $\begin{array}{c}\text { Std. Error of the } \\
\text { Estimate }\end{array}$ \\
\hline 1 & $0.567^{\mathrm{a}}$ & 0.321 & 0.300 & 1.90242 \\
\hline
\end{tabular}

Based on Table 4, there is a coefficient of determination which can be seen from the $\mathrm{R}$ square value of 0.321 . From these results, it shows that the ability of the promotion variable $\left(\mathrm{X}_{1}\right)$, product innovation $\left(\mathrm{X}_{2}\right)$ and price $(\mathrm{Z})$ to purchase decisions $(\mathrm{Y})$ is $32.1 \%$, while $67.9 \%$ can be explained outside the variables

\section{Sobel Test Result}

Testing the mediation hypothesis can be done by using the Sobel test, which was developed by Sobel in 1982 (Selda \& Ömer, 2019). Sobel test can be done by testing the indirect effect of the independent variable with the dependent variable through the mediating variable. The $p$ value is $<0.05$ significance, so the effect of mediation can be ignored (Sunyoto, 2017). The result of Sobel Test is presented in Figure 1.

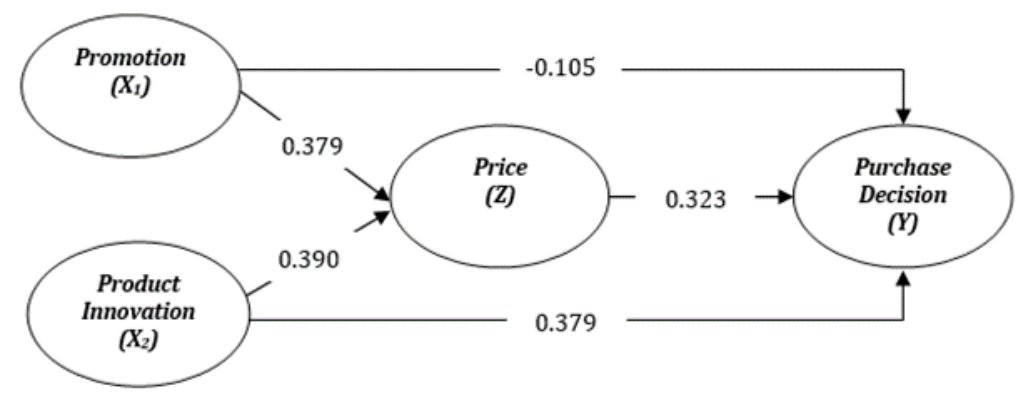

Figure 1. Sobel Test Result

\section{Direct Effect}

$\mathrm{X}_{1} \rightarrow \mathrm{Z}=0.379$

$\mathrm{X}_{2} \rightarrow \mathrm{Z}=0.390$

$\mathrm{X}_{1} \rightarrow \mathrm{Y}=-0.105$

$\mathrm{X}_{2} \rightarrow \mathrm{Y}=0.379$

$$
\begin{aligned}
& \text { Indirect Effect } \\
& X_{1} \rightarrow Z \rightarrow Y=0.122 \\
& X_{2} \rightarrow Z \rightarrow Y=0.126 \\
& \text { Total Effect } \\
& X_{1} \rightarrow Z \rightarrow Y=0.379+0.323=0.702 \\
& X_{2} \rightarrow Z \rightarrow Y=0.390+0.323=0.713
\end{aligned}
$$

From the calculation formula, $\mathrm{p}$-value $\mathrm{X}_{1} \rightarrow \mathrm{Z} \rightarrow \mathrm{Y}$ is 0.022 and $\mathrm{p}$-value $\mathrm{X}_{2} \rightarrow \mathrm{Z} \rightarrow \mathrm{Y}$ is 0.021 . Based on these resulted, it can be seen that this research variable had a mediating effect by the price variable between the promotion and product innovation variables on purchasing decisions. 


\section{Discussions}

Hypothesis tested needs to be done in order to determine the directed relationship between variables. With this hypothesis tested, the previously proposed hypothesis can be known directly. The alternative hypothesis will be accepted if the probability is less than or equal to the significance level of 0.05 (Kotler, 2009).

\section{Promotion Towards Purchase Decisions}

Based on the resulted of the hypothesis in table 3 above, it can be seen that the first hypothesis the promotion variable did not have a positive effect on purchasing decisions, using a significance level of 0.05. In this case, the hypothesis from $\mathbf{H}_{1}$ : There was a positive and significant relationship between promotion and purchasing decisions is rejected. This hypothesis is supported by previous research which concluded that promotion variables had an insignificant effect on purchasing decisions (Abdillah, 2017). This can be seen in Table 3 where the significance level is 0.365 , where $0.365>0.05$ means the variable was declared insignificant and the hypothesis is rejected. This showed that the promotions carried out by the Tokopedia and Shopee platforms do not affect consumer purchasing decisions. This was because the promotions carried out cannot stand alone if they are not juxtaposed with price variables, where consumers from Tokopedia and Shopee see prices instead of promotions as a reference in determining purchasing decisions. This means that people who used the Tokopedia and Shopee platforms admit that in buying their products they have no reference based on the promotions given.

\section{Product Innovation Towards Purchase Decisions}

The second hypothesis was that the product innovation variable had a positive effect on purchasing decisions, used a significance level of 0.05 . So the hypothesis of $\mathbf{H}_{2}$ : There was a positive and significant relationship between Product Innovation and purchasing decisions is accepted. It can be seen from table 3 where the significance level is 0.002 , where $0.002<0.05$, the variable is declared significant and the hypothesis is accepted. This is in line with the research which states that there was a significant effect of product innovation on purchasing decisions. If the product has an interesting product innovation, consumers will be interested in made a purchase (Setiawan et al., 2018). This showed that the product innovation carried out by the Tokopedia and Shopee platforms greatly influences consumer purchasing decisions directly without going through the price variable. This is because the product innovations carried out by the two platforms are very varied and can form the basis for decision making. This means that people who used the Tokopedia and Shopee platforms admitted that in buying products they always see what product innovations are provided by Tokopedia and Shopee so that if they feel that the innovation provided is in accordance with their needs, consumers will buy it regardless of the price given by the platform.

\section{Price Mediate Between Promotion and Product Innovation on Purchase Decisions}

Based on Sobel test resulted, it can be concluded that the third hypothesis and the fourth price variables mediate the relationship between promotion and product innovation on purchasing decisions are accepted. The resulted displayed in Sobel test indicate that the p-value is less than the significance level of 0.05 where the p-value is $0.022<0.05 ; 0.021<0.05$. Thus, that there was a price mediation effected which is related to product promotion and innovation on purchasing decisions so that $\mathbf{H}_{3}$ and $\mathbf{H}_{4}$ were accepted. This was in line with research which states that there was a positive and significant relationship between product promotion and innovation on purchasing decisions with price as an intervening variable (Dharma, 2017). This showed that the promotion and product innovation carried out by the Tokopedia and Shopee platforms also greatly influences consumer purchasing decisions through price variables. The reason is, the product prices provided by the two platforms are very appropriate when juxtaposed with the promotions and product innovations given. This means that people who used the Tokopedia and Shopee platforms admitted that in buying products, they always see price as a benchmark, whether the price given is in accordance with the promotions and innovations that are obtained. Consumers will buy products if the price paid is reasonable with the promotion and product innovation they get

\section{CONCLUSION}

Based on the resulted and discussion above, it can be seen based on 4 research problems. The resulted of this study prove that there is no positive influence on purchasing decisions on the Tokopedia and Shopee platforms, then product innovation has a positive effect on purchasing decisions directly on the Tokopedia and Shopee platforms. However, in this study, the role of price as a mediating variable is 
proven to mediate product promotion and innovation. Promotions carried out by Tokopedia and Shopee cannot have a direct impact on consumers without going through prices, because they will make purchasing decisions by looking at prices, not just from promotions made by Tokopedia and Shopee. On the other hand, the product innovations carried out by Tokopedia and Shopee have a direct and indirect impact through price. Consumers can make purchasing decisions directly without looking at the price provided that the product innovation is provided according to their needs, but consumers can also make purchasing decisions by looking at prices assuming a reasonable price and in accordance with the product innovation given.

\section{REFERENCES}

Abdillah, A. T. (2017). Pengaruh Promosi Dan Inovasi Produk Terhadap Kepuasan Konsumen Dan Dampaknya Terhadap Keputusan Pembelian Ulang Pada Online Shop Miulan Hijab. Universitas Nusantara PGRI Kediri, 01, 1-7. http://eprints.undip.ac.id/58803/.

Ainiyah, N. (2018). Remaja Millenial dan Media Sosial: Media Sosial Sebagai Media Informasi Pendidikan Bagi Remaja Millenial. Jurnal Pendidikan Islam Indonesia, 2(2), 221-236. https://doi.org/10.35316/jpii.v2i2.76.

Arief Budhi Dharma, Y. T. D. (2017). Marketing Mix Terhadap Keputusan Dengan Harga Sebagai Intervening (Studi Kasus Pada SMKN I Surakarta). Gema, 30(52), 2473-2499. https://www.neliti.com/publications/62208/marketing-mix-terhadap-keputusan-dengan-hargasebagai-intervening-studi-kasus-pa.

Christian A.D Selang. (2013). Bauran Pemasaran (Marketing Mix) Pengaruhnya Terhadap Loyalitas Konsumen Pada Fresh Mart Bahu Mall Manado. Jurnal Riset Ekonomi, Manajemen, Bisnis Dan Akuntansi, 1(3), 71-80. https://doi.org/10.35794/emba.v1i3.1374.

Djodjobo Vanessa, C., \& N.Tawas, H. (2014). Pengaruh Orientasi Kewirausahaan, Inovasi Produk, dan keunggulan Bersaing Terhadap Kinerja Pemasaran Usaha Nasi Kuning di Kota Manado. September 2017, Vol.2 No.3. https://doi.org/10.35794/emba.v2i3.5800.

Ghozali, I., \& Latan, H. (2012). Partial Least Square: Konsep, Teknik dan Aplikasi SmartPLS 2.0 M3. Semarang: Badan Penerbit Universitas Diponegoro., Semarang: https://digilib.undip.ac.id/v2/2012/10/05/partial-least-squares-konsep-teknik-dan-aplikasismartpls-20-m3/.

Hamdani, A. U., Informasi, S., Informasi, F. T., Luhur, U. B., Utara, P., \& Lama, K. (2020). Penjualan Online Berbasis E-Commerce Pada $\quad$ Toko. 26-34. https://jom.fti.budiluhur.ac.id/index.php/IDEALIS/article/view/1476.

Handayani, S. (2018). Perancangan Sistem Informasi Penjualan Berbasis E-Commerce Studi Kasus Toko

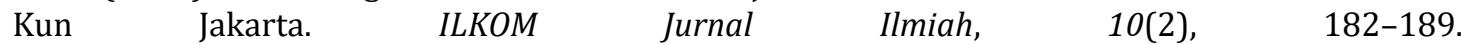
https: //doi.org/10.33096/ilkom.v10i2.310.182-189.

Japarianto, E., \& Adelia, S. (2020). Pengaruh Tampilan Web Dan Harga Terhadap Minat Beli Dengan Kepercayaan Sebagai Intervening Variable Pada E-Commerce Shopee. Jurnal Manajemen Pemasaran, 14(1), 35-43. https://doi.org/10.9744/pemasaran.14.1.35-43.

Kharis, M. N. (2017). Pengaruh Kualitas Pelayanan Terhadap Kepuasan Pelanggan Dengan Harga Sebagai Intervening (Studi Pada Bengkel Raden Motor Blitar). http://etheses.uinmalang.ac.id/id/eprint/10564.

Khoirul Akhiri, N. (2018). Pengaruh Inovasi Produk Dan Harga Terhadap Keputusan Pembelian Yamaha Mio M3 Bluecore(Studi Pada Konsumen Yamaha Mio M3 Bluecore Di Surabaya Pusat). Jurnal Ilmu Manajemen (JIM), 4(4), 1-8. https://ejournal.unesa.ac.id/index.php/jim/article/view/17496.

Kotler, Phillip. Keller, K. L. (2009). Manajemen Pemasaran. Jilid 1. Jakarta: Indeks, Kelompok Gramedia 2009.

Margaretha, F. (2017). Analisis Hubungan Antara Motif Dengan Tingkat Kepuasan Pengguna Aplikasi Shopee Sebagai Media Berbelanja Online PAD SHOPEEHOLIC Di Kota Samarinda. EJournal Ilmu Komunikasi, $\quad$ 5(4), 26-40. https://ejournal.ilkom.fisip-unmul.ac.id/site/wpcontent/uploads/2017/10/eJournal Ilmu Komunikasi (10-13-17-02-49-05).pdf.

Masda, P. G. (2019). 7/18/2019 Pengaruh Inovasi Produk dan Harga Terhadap Keputusan Pembelian Galamai Di Kota Payakumbuh. Dokumen, 1-12. https://dokumen.tips/download/link/pengaruhinovasi-produk-dan-harga-terhadap-keputusan-pembelian-galamai-di-kota.

Prayoga, A., \& Suseno, E. (2020). The Positive Impact of Rebranding to Increasing Consumer loyality with Brand Image as the Mediating Variable. International Journal of Social Science and Business, 4(4), 561. https://doi.org/10.23887/ijssb.v4i4.28340.

Prilano, K., \& Sudarso, A. (2020). Pengaruh Harga , Keamanan dan Promosi Terhadap Keputusan 
Pembelian Toko Online Lazada. Journal of Business and Economics Research, 1(1), 1-10. https://ejurnal.seminar-id.com/index.php/jbe/article/view/56/42.

Rasyid, H. Al, \& Indah, A. T. (2018). Pengaruh Inovasi Produk dan Harga Terhadap Keputusan Pembelian Sepeda Motor Yamaha di Kota Tangerang Selatan. Jurnal Ekonomi Dan Manajemen Universitas Bina Sarana Informatika, XVI(1). https://doi.org/10.31294/jp.v16i1.3031.

Reza, F. (2017). Strategi Promosi Penjualan Online Lazada.Co.Id. Jurnal Kajian Komunikasi, 4(1), 64-74. https://doi.org/10.24198/jkk.vol4n1.6.

Schiffman, G. L., \& Leslie Lazar, K. (2006). Perilaku Konsumen. Jakarta: Indeks Kelompok Gramedia, Edisi 7.

Sekar. (2017). The Effect Of Product Innovation, Store Atmosphere, And Location On Consumer Decisions Through Consumer Motivation. Вестник Казнму, №3, с.30.

Selda Örs, Ö., \& Ömer, K. (2019). Investigation of the Mediator Variable Effect Using BK, Sobel and Bootstrap Methods ( Mathematical Literacy Case ). International Journal of Progressive Education, 15(2), 30-43. https://doi.org/10.29329/ijpe.2019.189.3.

Setiawan, A. T., DH, A. F., \& Sanawiri, B. (2018). Pengaruh Gaya Hidup Dan Inovasi Produk Terhadap Keputusan Pembelian (Survei pada Mahasiswa S1 Jurusan Ilmu Administrasi Bisnis Angkatan 2014 / 2015 Fakultas Ilmu Administrasi Universitas Brawijaya Malang yang Membeli, Menggunakan dan Mengetahui Smartphon. Jurnal Administrasi Bisnis, 62(1), 73-81. http://administrasibisnis.studentjournal.ub.ac.id/index.php/jab/article/view/2651.

Setyarko, Y. (2016). Analisis Persepsi Harga, Promosi, Kualitas Pelayanan, dan Kemudahan Penggunaan Terhadap Keputusan Pembelian Produk Secara Online. Ekonomika Dan Manajemen, ISSN: 22526226, 5(2), 128-147. http://fe.budiluhur.ac.id/wp-content/uploads/2017/08/b.-Yugi_Analisispersepsi-harga_rev.pdf.

Siti Lam'ah, N., Christine Herawati, L., \& Denny Ammari, R. (2018). Pengaruh Kualitas Produk, Citra Merek, Kepercayaan, Kemudahan, Dan Harga Terhadap Keputusan Pembelian Pada E-Commerce Shopee. Ecobisma (Jurnal Ekonomi, Bisnis Dan Manajemen), 43-53. https://doi.org/10.36987/ecobi.v7i1.1528.

Solihin, D. (2020). Pengaruh Kepercayaan Pelanggan dan Promosi Terhadap Keputusan Pembelian Konsumen Pada Online Shop Mikaylaku Dengan Minat Beli Sebagai Variabel Intervening. 4(1), 26-37. https://doi.org/10.33753/mandiri.v4i1.99.

Sriyanto, A. (2019). Pengaruh Brand Ambassador, Minat Beli, Dan Testimoni Terhadap Keputusan Pembelian (Studi Pada Situs Jual Beli Online Shop Shopee Indonesia di Universitas Budi Luhur Periode Februari - April 2018). Jurnal Ekonomika Dan Manajemen, 8(1), 21-34. https://journal.budiluhur.ac.id/index.php/ema/article/view/858/660.

Sunyoto, D. (2017). Dasar-dasar Manajemen Pemasaran. Cet .1. Yogyakarta: CAPS (Center of Academic Publishing Service).

Widyastuti, P. (2018). Kata Kunci: gaya hidup, kualitas, harga, organik Quality and Prices as The Most Important Variable on Organic Vegetables Purchasing Decision. Ekspektra: Jurnal Bisnis Dan Manajemen, 2,

17-28. https://ejournal.unitomo.ac.id/index.php/manajemen/article/view/675/397. 